\title{
PENGEMBANGAN MEDIA PELAJARAN BERBASIS APLIKASI ANDROID DENGAN AUGMENTED REALITY UNTUK MATA PELAJARAN GAMBAR TEKNIK KELAS X KONTRUKSI GEDUNG, SANITASI DAN PERAWATAN DI SMK NEGERI 1 SEYEGAN
}

\author{
Nuryadin Eko Raharjo ${ }^{1}$ dan Galuh Kemuning Pitaloka ${ }^{2}$ \\ 1,2, Pendidikan Teknik Sipil dan Perencanaan, FT, UNY \\ Email: nuryadin_er@uny.ac.id
}

\begin{abstract}
ABSTRAK
Kajian ini bertujuan untuk mengembangkan media pembelajaran berbasis aplikasi android dengan augmented reality pada mata pelajaran Gambar Teknik dengan model Waterfall. Kajian ini merupakan penelitian Research and Development $(R \& D)$ dengan menggunakan model pengembangan Linear sequential model atau Waterfall Model. Model Waterfall dilaksanakan melalui tahapan analisis, desain, pengodean, dan pengujian. Hasil kajian ini sebagai berikut. (1) Pada tahap analisis diketahui bahwa siswa diperbolehkan menggunakan memakai smartphone sebagai media pembelajaran, media pembelajaran masih kurang variatif dan metode guru mengajar masih konvensional. Software yang digunakan adalah Unity 3D, Corel Draw X8, dan Adobe Photoshop CS6. Spesifikasi minimum smartphone yang dibutuhkan android versi 4.0 Jellybean, RAM 768 MB dan kamera 5 $M P$. (2) Tahap desain menghasilkan rancangan Unified Modeling Language (UML), dan desain antarmuka (user interface). (3) Pada tahap pengodean dihasilkan aplikasi android, implementasi dari desain Unified Modeling Language (UML) dan desain antarmuka (user interface). (4) Tahap pengujian dilaksanakan dengan uji materi dan uji media menurut ISO 25010. Hasil uji materi oleh ahli materi dari aspek kualitas isi dan tujuan serta aspek kualitas pembelajaran memperoleh nilai presentase 92,7\% kategori sangat Layak. Pengujian aspek functional suitability oleh ahli media memperoleh nilai presentase $100 \%$ berada pada kategori sangat layak. Aspek compatibility sub kategori co-existence dan hasil uji pada berbagai tipe perangkat masing-masing memperoleh skor 100\% dengan kategori sangat layak. Pengujian aspek usability memperoleh skor 79,8 dengan kategori baik. Aspek performance efficiency telah memenuhi standar dan berada pada performance efficiency yang baik.
\end{abstract}

Kata kunci: Augmented Reality, Gambar Teknik, SMK

\begin{abstract}
This study aims to developing learning media based on android application with augmented reality in the subject of technical drawing learning. The Research used Research and Development $(R \& D)$ method using linear sequential model development or commonly called the Waterfall Model. the stage of Waterfall Model was analysis, design, coding, and testing. The results of this research as follows. (1) The stage of analysis obtained problems by students use of smartphones while learning, the lacks variety of the media and the teaching methods are still conventional. The software used is Unity 3D, Corel Draw X8, and Adobe Photoshop CS6. The least smartphone hardware needed is Android 4.0 Jellybean with 768 MB RAM and 5 MP camera. (2) The design stage results in a design in the form of a Unified Modeling Language (UML), and an interface design (user interface). (3) The coding stage results is the form of an android application which are the results of the Unified Modeling Language $(U M L)$ design implementation and the user interface. (4) The Testing stage consists of material test and media test according to ISO 25010. The feasibility of the media in terms of quality content and aims as well as aspects of learning quality get score of $92.7 \%$ with the category very decent. In the functional suitability aspect, media experts get a percentage value of $100 \%$ with the category very decent. Co-existence sub-group compatibility aspects and test results on various types of devices each score 100\% with the category very decent. Then in the usability aspect, it gets a score of 79.8 and is in the good category. In the aspect of performance efficiency obtains results according to standards and is at a good performance efficiency.
\end{abstract}

Keywords: Augmented Reality, Technical Drawing, SMK

JPTS, Vol. II No. 1, Juni 2020 


\section{PENDAHULUAN}

Sekolah Menengah Kejuruan (SMK) adalah bentuk satuan pendidikan yang orientasinya memberi bekal siswa untuk memasuki lapangan kerja tingkat menengah dan melanjutkan pendidikan ke jenjang yang sesuai dengan kejuruannya. Kegiatan pembelajaran tidak hanya terjadi di sekolah, namun kegiatan praktik industri di dunia kerja nyata sangat ditekankan untuk mendapatkan dan meningkatkan pengalaman bekerja.

Revolusi industri 4.0 yang sedang dihadapi masyarakat dunia harus benarbenar diperhatikan oleh dunia pendidikan di Indonesia termasuk SMK. Yahya (2018) mengatakan dalam pidato pengukuhan gelar Profesornya, tantangan dan peluang industri 4.0 mendorong inovasi dan kreasi pendidikan kejuruan. Ia melanjutkan, pemerintah perlu meninjau relevansi antara pendidikan kejuruan dan pekerjaan untuk merespon perubahan, tantangan, dan peluang era industri 4.0 dengan tetap memperhatikan aspek kemanusiaan (humanities). pembelajaran yang dilaksanakan di SMK haruslah mempunyai korelasi dengan dunia industri yang tengah berevolusi. Baik dari sumber informasi maupun kompetensi yang diajarkan.

Menurut Trillling dan Fadel (2009:21), pembelajaran abad 21 berorientasi pada gaya hidup digital, alat berpikir, penelitian pembelajaran dan cara kerja pengetahuan Tiga dari empat orientasi pembelajaran abad 21 sangat dekat dengan pendidikan kejuruan yaitu cara kerja pengetahuan, penguatan alat berpikir, dan gaya hidup digital. Cara kerja pengetahuan merupakan kemampuan berkolaborasi dalam tim dengan lokasi yang berbeda dan dengan alat yang berbeda, penguatan alat berpikir merupakan kemampuan menggunakan teknologi, alat digital, dan layanan, dan gaya hidup digital merupakan kemampuan untuk menggunakan dan menyesuaikan dengan era digital.
Gaya hidup digital masyarakat Indonesia dapat terlihat dari tingkat penggunaan smartphone-nya. Penggunaan smartphone di Indonesia mengalami kenaikan dari tahun ke tahun. Lembaga riset digital marketing Emarketer, Indonesia akan melampaui 100 juta pengguna smartphone aktif pada tahun 2018, menjadikannya negara dengan populasi pengguna smartphone terbesar keempat di dunia (di belakang China, India, dan Amerika Serikat).

Kementrian Riset dan Perguruan Tinggi (Menristekdikti) menyebutkan angka penggunaan smartphone di Indonesia pada tahun 2017 mencapai $25 \%$ dari total penduduk atau sekitar 65 juta orang (ristekdikti.go.id, 11 Januari 2017). Perkembangan ini dapat dilihat dari hasil sebuah laporan dari Emarketer yang menyatakan bahwa penggunaan smartphone aktif akan semakin meningkat khususnya Negara Indonesia.

Kegiatan dunia maya juga harus ditambah dengan kegiatan yang berhubungan dengan pendidikan. Memang sudah ada beberapa website atau aplikasi yang menawarkan kegiatan pendidikan misalnya saja quipper, ruangguru, zenius dan lain-lainnya untuk memberikan bimbingan belajar secara online dengan harga murah dibanding bimbingan belajar komersil. Sayangnya peminat website atau aplikasi dengan kategori pendidikan belum sebanyak kategori shopping.

Survei yang dilakukan DI Marketing pada 2016 menyebutkan bahwa pengguna smartphone usia sekolah (dibawah 18 tahun) paling banyak digunakan untuk bermain game. Bahkan, seringkali didapati siswa di kelas menggunakan smartphone untuk bermain game yang tidak berhubungan dengan pelajaran pada saat KBM berlangsung. Tindakan yang dilakukan guru saat mendapati hal tersebut adalah menyita smartphone siswa yang bersangkutan. Smartphone sering dianggap membawa dampak negatif khususnya di sekolah. Budaya literasi siswa menurun, dikarenakan 
begitu mudahnya informasi diakses melalui smartphone. Siswa juga kadang tidak fokus dalam kegiatan pembelajaran karena asik bermain smartphone. Alangkah baiknya jika potensi smartphone dimanfaatkan sebagai media dalam pembelajaran, mengingat smartphone sendiri sudah menjadi lifestyle siswa. Pemanfaatan teknologi informasi dan komunikasi memungkinkan siswa meningkatkan pemahaman sebuah materi pada proses belajar mengajar serta dapat belajar secara mandiri dan kreatif.

Kegiatan belajar mengajar di SMK sudah harus berevolusi. Sistem belajar mengajar di SMK harus berjalan beriringan dengan kemajuan zaman. Fakta saat ini adalah era digital dimana terjadi peralihan kegiatan manusia ke dalam dunia digital haruslah dipikirkan serius khususnya oleh tenaga pendidik. Pembelajaran harusnya memanfaatkan perkembangan teknologi dalam pelaksanaannya. Bukannya mempertahankan budaya dahulu karena sudah tidak sesuai dengan zaman saat ini.

Pembelajaran gambar teknik di SMK secara kontekstual dan ceramah akan kurang mampu untuk mengatasi ketidakpahaman siswa terhadap materi. Keberadaan media pembantu seperti media pembelajaran yang interaktif dengan mendukung fasilitas fitur tiga dimensi akan sangat membantu pelakasanaan pembelajaran yang mengalami kekurangan media pendukung pembelajaran. Pemanfaatan media yang dimaksud, media yang mendukung meningkatkan kemampuan spasial atau kemampuan untuk membayangkan suatu objek dalam ruang. Media pembelajaran sebatas jobsheet, masih kesulitan membantu siswa untuk membayangkan dan memahami proyeksi dalam objek tertentu. Hal tersebut harus didukung dengan benda 3 dimensi disertai oleh animasi. Media yang tepat untuk menunjang kegiatan pembelajaran pada kompetensi dasar gambar proyeksi orthogonal (2D) sesuai aturan proyeksi yaitu media pembelajaran dengan augmented reality.
Menurut Azuma (1997:2) Augmented Reality (AR) merupakan teknologi yang menggabungkan benda maya dua dimensi ataupun tiga dimensi ke dalam sebuah lingkungan nyata tiga dimensi lalu memproyeksikan benda-benda maya tersebut secara realtime. Apabila teknologi ini diterapkan dalam bidang pendidikan pada kompetensi dasar mata pelajaran gambar teknik yaitu menerapkan gambar proyeksi orthogonal (2D) sesuai aturan proyeksi sehingga siswa akan lebih tertarik terhadap minat belajar.

Berdasarkan uraian tersebut, media pembelajaran yang dapat dikembangkan untuk mendukung pembelajaran Gambar Teknik di SMK adalah media pembelajaran berbasis aplikasi android dengan augmented reality. Media tersebut diyakini akan menambah ketertarikan siswa serta meningkatnya motivasi belajar dan pembelajaran menjadi efektif. Penggunaan teknologi augmented reality diharapkan mampu memberi dampak positif belajar siswa dalam materi proyeksi orthogonal sehingga nantinya siswa dapat meningkatkan pemahaman siswa dalam belajar serta memberi kesempatan kepada siswa untuk belajar secara mandiri dan efektif.

Safaat (2015: 1) mengemukakan bahwa android merupakan sistem operasi untuk perangkat Mobile berbasis linux yang mencakup sistem operasi, middleware dan aplikasi. Android menyediakan platform yang open source (terbuka) bagi para pengembang untuk membangun aplikasi mereka. Android sendiri diciptakan oleh perusahaan Google yang bekerjasama dengan Open Handset Alliance. Android menurut Satyaputra \& Aritonang (2014: 2) adalah sebuah sistem operasi untuk smartphone dan tablet. Sistem operasi dapat diilustrasikan sebagai jembatan antara piranti (device) dan penggunaannya, sehingga pengguna dapat berinteraksi 
dengan devicenya dan menjalankan aplikasiaplikasi yang tersedia pada device.

Menurut Huda (2013: 4-5) komponen aplikasi merupakan bagian penting dari sebuah android. Setiap komponen mempunyai fungsi yang berbeda, dan antara komponen satu dengan yang lainnya bersifat saling berhubungan. Berikut ini komponen aplikasi yang harus diketahui, yaitu:

1) Activity

Activity merupakan satu halaman antarmuka yang bisa digunakan oleh user untuk berinteraski dengan aplikasi. Biasanya dalam satu activity terdapat button, spinner, list view, edit text, dan sebagainya. Satu aplikasi dalam Android dapat terdiri atas lebih dari satu activity.

\section{2) Services}

Services merupakan komponen aplikasi yang dapat berjalan secara background, misalnya digunakan untuk memuat data dari server database. Selain itu, aplikasi pemutar musik atau radio juga memanfaatkan servis supaya aplikasinya bisa tetap berjalan meskipun pengguna melakukan aktivitas dengan aplikasi lain.

\section{3) Contact Provider.}

Komponen ini digunakan untuk mengelola data sebuah aplikasi, misalnya kontak telepon. Siapapun bisa membuat aplikasi android dan dapat mengakses kontak yang tersimpan pada sistem android. Oleh karena itu, agar dapat mengakses kontak, user memerlukan komponen contact provider.

4) Broadcast Receiver.

Fungsi komponen ini sama seperti bahasa terjemahannya yaitu penerima pesan. Kasus beterai lemah merupakan kasus yang sering dialami handphone android. Sistem android dirancang untuk menyampaikan "pengumuman" secara otomatis jika baterai habis. Apabila aplikasi yang dibuat dilengkapi dengan komponen broadcast receiver, maka user dapat mengambil tindakan menyimpan kemudian menutup aplikasi atau tindakan yang lain.

Aplikasi android merupakan suatu media yang tergolong dalam media pembelajaran bentuk elektronik, karena produk aplikasi android tersebut dijalankan pada smartphone dan gadget bersistem operasi android. Yang mana smartphone dan gadget tersebut termasuk salah satu teknologi komunikasi. Atas dasar tersebutlah media pembelajaran berbasis aplikasi android dikatakan sebagai media elektronik. Penggunaan smartphone sebagai media pembelajaran juga akan memberikan pengalaman yang baru bagi siswa dan akan lebih memudahkan siswa dalam belajar karena bentuknya yang simpel serta aksesnya yang luas sehingga smartphone mudah digunakan kapan saja dan dimana saja.

Herlandy et all (2019: 195) mengemukakan bahwa media pembelajaran berbasis mobile adalah media pembelajaran yamg tertanam dalam ponsel perangkat telekomunikasi, khususnya yang menggunakan smartphone. Bentuk-bentuk teknologi pembelajaran yang ditampilkan di perangkat ponsel dapat berupa e-book, game, dan simulasi. Melalui mobile learning siswa dapat mengakses materi pelajaran dan informasi dari mana saja dan kapan saja. Siswa tidak perlu menunggu waktu tertentu untuk belajar atau pergi ke tempat tertentu untuk belajar. Jumlah perangkat mobile lebih banyak daripada PC. Perangkat mobile lebih mudah dioperasikan daripada PC. Perangkat mobile dapat digunakan sebagai media belajar.

Seiring berkembangnya teknologi dalam bidang pendidikan bertambah juga jenis media yang digunakan guru dalam pembelajarannya. Saat ini terdapat teknologi yang tengah diminati oleh penikmat teknologi dimana pelaksanaannya menggabungkan dua dimensi yang berbeda. Teknologi tersebut adalah augmented reality. Menurut Ismail et all (2018:179) penggunaan teknologi seperti augmented reality dalam pengajaran sangat membantu siswa dalam meningkatkan kemampuan visualisasi mereka.

Menurut Azuma (1997:2) Augmented Reality (AR) merupakan teknologi yang 
menggabungkan benda maya dua dimensi dan ataupun tiga dimensi ke dalam sebuah lingkungan nyata tiga dimensi lalu memproyeksikan benda-benda maya tersebut secara realtime. Benda-benda maya menampilkan informasi berupa label maupun obyek virtual yang hanya dapat dilihat dengan kamera handphone maupun dengan komputer. Menurut Brian (2012:253), Augmented Reality (AR) adalah sebuah istilah untuk lingkungan yang menggabungkan dunia nyata dan dunia virtual yang dibuat oleh komputer sehingga batas antara keduanya menjadi sangat tipis. Sistem ini lebih dekat kepada lingkungan nyata (real). Karena itu, reality lebih diutamakan pada sistem ini.

Tujuan augmented reality adalah menambahkan informasi, gambar dan objek 3D kepada sebuah latar dunia nyata. Augmented reality tidak sama dengan Virtual Reality, Augmented Reality tidak membuat sebuah latar tempat sebagai simulasi kenyataan (simulation of reality). Sebaliknya, dibutuhkan sebuah objek atau latar dunia nyata sebagai fondasi dan teknologi incorporate sebagai tempat target menambahkan data virtual. Suryanto et al (2018:33) menerangkan AR akan bekerja melalui deteksi gambar yang biasa disebut marker atau penanda dengan menggunakan kamera smartphone lalu mendeteksi marker yang sudah dicetak.

Adapun proses kerja augmented reality menurut Riadi (2017) adalah sebagai berikut:

1) Kamera menangkap data dari marker dalam dunia nyata dan mengirimkan informasinya ke komputer.

2) Software pada komputer akan melacak bentuk kotak dari marker dan mendeteksi berapa video framenya.

3) Bila kotak telah ditemukan, maka software menggunakan perhitungan matematis untuk menghitung posisi dari kamera relative terhadap kotak hitam pada marker.

4) Setelah dikalkulasi maka model grafis akan dimunculkan pada posisi yang sama dan berada di dalam lingkup kotak hitam, lalu ditampilkan ke layar untuk melihat grafis dalam dunia nyata

Pada teknologi augmented reality terdapat istilah marker. Marker merupakan wadah/tempat untuk menampilkan objek 3D buatan. Marker Based Tracking adalah salah satu jenis augmented reality yang memerlukan marker sebagai penanda/target. Aplikasi augmented reality akan membaca marker kemudian memunculkan objek 3D atau 2D sesuai ukuran marker dari sumbu $X$, $\mathrm{Y}$ dan $\mathrm{Z}$ dan $(0,0,0)$.

Mata Pelajaran gambar teknik di jurusan Konstruksi Gedung, Sanitasi dan Perawatan SMK N 1 Seyegan merupakan kategori Pelajaran produktif dimana diarahkan pada penguasaan dasar sesuai dengan kebutuhan di lapangan. Gambar teknik merupakan bahasa teknik yaitu suatu alat untuk menyampaikan informasi. Informasi yang disampaikan adalah dari seorang juru gambar (drafter) atau orang yang membuat gambar. Oleh karena itu siswa harus dibekali dengan materi yang relevan.

Pada Mata Pelajaran gambar teknik terdapat materi menerapkan gambar proyeksi orthogonal (2D) sesuai aturan proyeksi paling sesuai dengan media yang dikembangkan. Materi ini sangat penting untuk dipelajari siswa sebagai bahan dasar pengetahuan untuk membuat sebuah gambar kerja. Proyeksi orthogonal dibagi menjadi sub materi antara lain, pengenalan proyeksi, Proyeksi Eropa dan Proyeksi Eropa. Pada materi proyeksi membutuhkan ruang tiga dimensi untuk memahami materi tersebut.

\section{METODE}

Kajian ini bertujuan mengembangkan aplikasi android dengan augmented reality sebagai media pembelajaran untuk mata pelajaran gambar teknik. Berdasarkan tujuan kajian, maka digunakan pendekatan penelitian dan pengembangan Research and Development (R\&D). Penelitian ini dilaksanakan di SMK Negeri 1 Seyegan. Responden dari kajian ini adalah guru mata 
pelajaran gambar teknik dan siswa kelas $\mathrm{X}$ Kompetensi Keahlian Konstruksi Gedung, Sanitasi dan Perawatan di SMK Negeri 1 Seyegan dan ahli media serta ahli materi.

Untuk mengembangkan sebuah sistem aplikasi dibutuhkan sebuah model pengembangan. Aplikasi ini dibangun dengan menggunakan model pengembangan perangkat lunak yakni model pengembangan sekuensial linier atau model Waterfall. Model Waterfall digambarkan sebagai berikut:

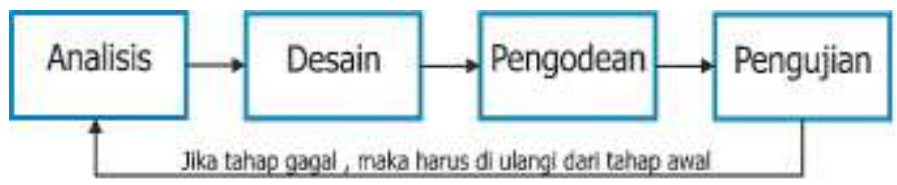

Gambar 1. Tahapan model Waterfall

Model Waterfall dipilih karena sistem yang akan dikembangkan adalah sistem dengan tingkat kompleksitas sedang dan memiliki kebutuhan yang jelas dan dapat dipahami oleh pengguna maupun pengembang. Model Waterfall terdiri dari tahap analisis, desain, pengodean, pengujian. Setiap tahap harus diselesaikan secara sistematik yang berarti tahap selanjutnya hanya akan dapat dilakukan jika tahap sebelumnya telah selesai. Kajian ini difokuskan pada pembuatan dan pengujian kualitas software media pembelajaran pada mata pelajaran gambar teknik.

1. Analisis

Analisis dilakukan sebagai tahap pertama untuk mengetahui kebutuhan apa saja yang diperlukan oleh user atau pengguna. Kajian literatur dilakukan untuk mengetahui konsep dan teori dasar sebagai landasan materi dalam aplikasi. Observasi dilakukan untuk mendapatkan informasi perancangan media pembelajaran berbasis android dengan augmented reality.

a. Analisis Permasalahan

Tahap analisis masalah dilakukan untuk menetapkan permasalahan yang tengah dihadapi siswa. Permasalahan yang ditemui didapat dari hasil observasi di sekolah yang diteliti.

b. Analisis Mata Pelajaran Gambar Teknik Materi Proyeksi Orthogonal

Berdasarkan silabus mata pelajaran gambar teknik yang digunakan diketahui kompetensi dasar materi proyeksi orthogonal. Setelah itu, dilakukan analisis materi yang akan digunakan dalam pengembangan aplikasi pembelajaran.

c. Analisis Kebutuhan Fungsional Media

Proses analisis kebutuhan difokuskan, khususnya pada perangkat lunak. Pada tahap ini dilakukan analisis terhadap kebutuhan hardware dan software apa saja yang diperlukan untuk mengembangkan media berbasis aplikasi android dengan augmented reality terhadap permasalahan siswa dalam kegiatan belajar mengajar pada mata pelajaran gambar teknik. Fungsi utama media pembelajaran ini adalah ilustrasi dalam bentuk Augmented Reality.

2. Desain

Pada tahap desain digunakan desain dalam bentuk Unified Modeling Language (UML), dan desain antarmuka (user interface). Diagram UML meliputi use case diagram, activity diagram, class diagram dan sequence diagram.

3. Pengodean

Pada pengodean, rancangan desain media direalisasikan sebagai serangkaian program android. Desain diterjemahkan dalam bahasa pemrograman $\mathrm{C}+$ dengan software Unity $3 D$ sehingga menghasilkan program yang diharapkan. Hasil dari tahap ini terdiri atas implementasi layout desain antarmuka (user interface) aplikasi dari diagram UML. Desain diwujudkan menjadi aplikasi pembelajaran berbasis android dengan augmented reality yang meliputi 
teks, gambar, animasi augmented reality dan musik.

\section{Pengujian}

Produk yang telah diwujudkan dalam bentuk media pembelajaran ini selanjutnya divalidasi oleh tim ahli dan pengguna. Tim ahli terdiri dari ahli materi dan ahli media. Pengujian yang dilakukan adalah uji materi dan uji media. Pengujian materi dilakukan menurut kriteria pemilihan media dari Walker dan Hess dengan dua aspek yakni kualitas isi dan tujuan serta aspek pembelajaran. Pengujian media dilakukan sesuai dengan standar ISO 25010. Empat macam pengujian yang dilakukan adalah functional suitability, compatibility, usability, dan performance efficiency. Apabila sistem telah memenuhi kriteria dan tidak perlu direvisi maka sistem siap untuk diujicobakan kepada para pengguna.

\section{HASIL DAN PEMBAHASAN}

Berdasarkan prosedur pengembangan dengan model pengembangan perangkat lunak, Linear sequential model atau model Waterfall. Model Waterfall terdiri dari empat tahapan, yaitu tahap analisis, desain, pengodean dan pengujian. Hasil yang diperoleh dari kajian pengembangan ini adalah media pembelajaran berbasis aplikasi android dengan augmented reality pada mata pelajaran gambar teknik.

\section{Analisis}

a. Analisis Permasalahan

Analisis permasalahan dilakukan untuk menetapkan permasalahan yang akan dihadapi. Pada tahap ini didapat permasalahan yang ditemui siswa dalam proses pembelajaran dari hasil observasi di SMK Negeri 1 Seyegan. Berikut data yang diperoleh dalam analisis permasalahan yang ditemui:
1) Saat pembelajaran berlangsung, banyak siswa malah menggunakan smartphone. Penggunaannya sendiri lebih pada kegiatan hiburan seperti bermain game, streaming dan kegiatan yang tidak berhubungan dengan pelajaran pada saat $\mathrm{KBM}$ berlangsung

2) Media pembelajaran untuk mata pelajaran Gambar Teknik pada Kompetensi Keahlian Konstruksi Gedung, Sanitasi dan Perawatan (KGSP) di SMK N 1 Seyegan belum bervariasi dan masih minim.

3) Proses pembelajaran masih menggunakan media pembelajaran konvensional seperti papan tulis. Guru menerangkan materi pengenalan gambar teknik dan siswa duduk mendengarkan dan mencatat.

4) Media konvensional dan metode ceramah menjadi pilihan guru dalam mengajar.

b. Analisis Mata Pelajaran Proyeksi Orthogonal

Materi yang akan digunakan dalam media pembelajaran berbasis aplikasi android dengan augmented reality sebagai berikut:

1) Definisi proyeksi dan Jenis-Jenis Proyeksi dan contoh penerapan.

2) Pengertian, karakteristik dan contoh penerapan Proyeksi Eropa.

3) Pengertian, karakteristik dan contoh penerapan Proyeksi Amerika

c. Analisis Kebutuhan Fungsional Media

Tahapan ini untuk menganalisis software dan hardware yang dibutuhkan untuk menunjang perancangan media pembelajaran ini. software yang dibutuhkan antara lain: 
Pengembangan Media Pelajaran... (Galuh/ hal. 65-77)

1) Unity 3D, software yang digunakan untuk mengembangkan atau merancang augmented reality untuk pembelajaran gambar teknik.

2) Corel Draw $X 8$, digunakan untuk mendesain background dan tombol yang ada dalam media.

3) Adobe Photoshop CS6, merupakan software yang digunakan untuk mengedit gambar dan icon yang ada di dalam media.

\section{Desain}

Perancangan pada pengembangan pembelajaran media ini meliputi Unifed Modeling Language (UML), perancangan antarmuka, dan perancangan marker. Tahap perancangan merupakan tahap yang dilakukan untuk merancang desain sistem media pembelajaran yang akan dikembangkan beserta tahap-tahap perancangan.

a. Perancangan Unifed Modeling Language (UML)

Perancangan Unified Modelling Language yang dipakai dalam penelitian ini mencakup empat unsur: (1) perancangan use case diagram, (2) perancangan activity diagram, perancangan class diagram dan perancangan sequence diagram.

Use Case merupakan pemodelan untuk kelakuan (behaviour) sistem yang akan dibuat. Perancangan use-case diagram ini dengan memberikan sebuah narasi dengan bentuk diagram sehingga nantinya berfungsi untuk mendeskripsikan interaksi antara pengguna dengan sistem. Pengguna masuk ke aplikasi kemudian muncul tampilan menu awal.
Squence diagram adalah diagram yang menggambarkan alur sistem pada setiap fungsionalitas untuk menggambarkan interaksi antar objek antar use-case dengan mendeskripsikan objek yang sedang berjalan kemudian pesan yang akan dikirimkan antara objek yang saling terkait. Sequence diagram memiliki beberapa fungsi, antara lain: (1) menampilkan proses kerja menampilkan menu proyeksi, (2) menampilkan proses kerja dalam menampilkan menu materi, serta (3) menampilkan proses kerja dalam menampilkan menu kuis.

Perancangan class diagram ini berfungsi untuk menggambarkan struktur sistem dari segi pendefinisian kelas-kelas yang akan dibuat untuk membangun sistem. Desain class diagram dari media pembelajaran ini ditunjukkan pada gambar berikut.

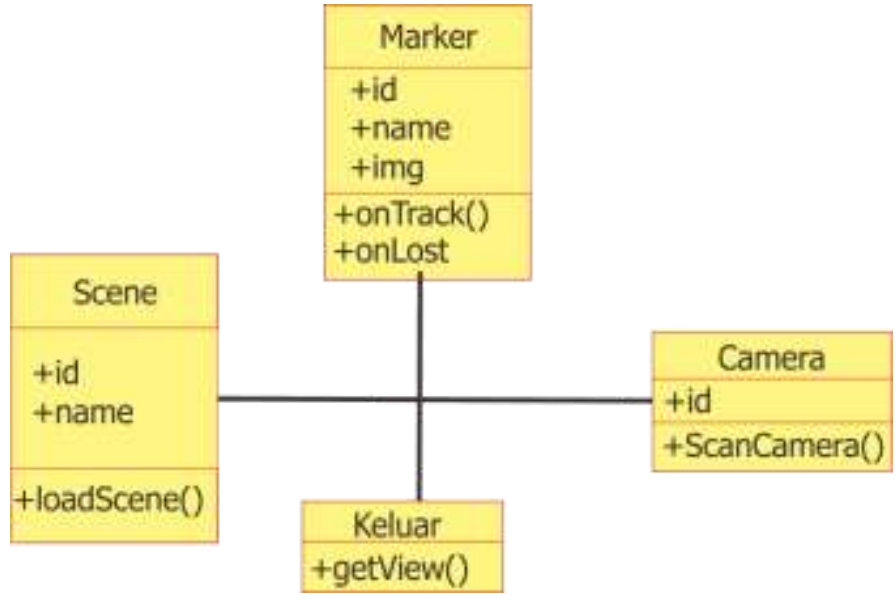

Gambar 2. Class Diagram Menu Proyeksi

Perancangan activity diagram berfungsi sebagai menggambarkan sebuah alur proses program secara keseluruhan dari perancangan awal atau proses penginstallan aplikasi hingga aplikasi ditutup. 


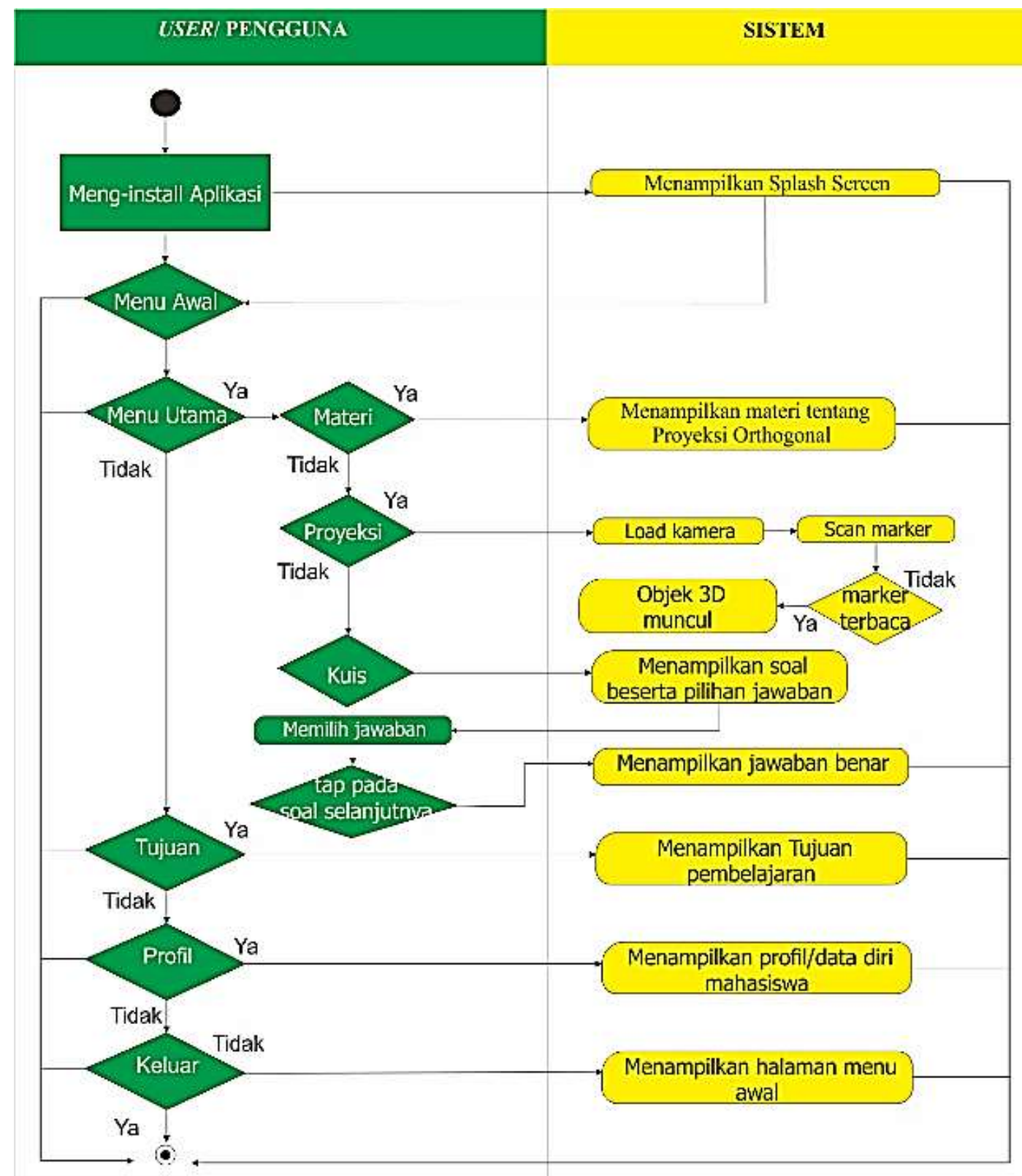

Gambar 3. Activity Diagram Aplikasi

b. Desain antarmuka (user interface)

Perancangan desain antarmuka atau user interface adalah tahap pembuatan desain tampilan utama dalam pengembangan media pembelajaran berbasis aplikasi android dengan augmented reality. Desain antarmuka dijelaskan dalam bentuk storyboard. Dalam storyboard terdapat desain scene aplikasi dan konten materi informasi yang ditampilkan.

c. Perancangan maker

Pada perancangan marker di aplikasi pembelajaran dengan augmented reality terdapat 3 objek untuk Proyeksi Eropa dan Proyeksi Amerika.
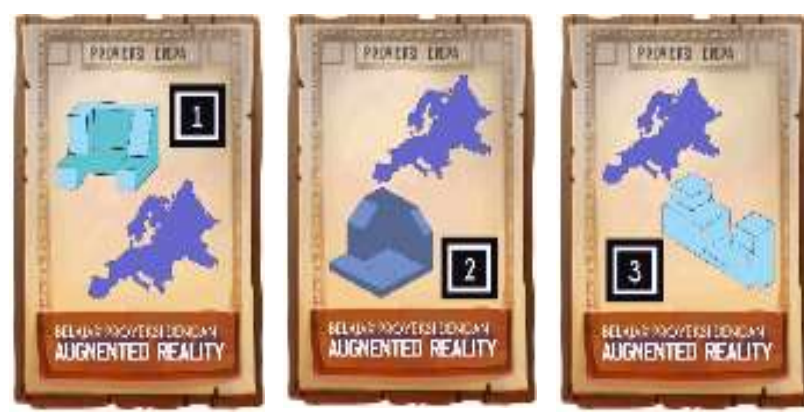

Gambar 4. Desain Marker Proyeksi Eropa 
Pengembangan Media Pelajaran... (Galuh/ hal. 65-77)

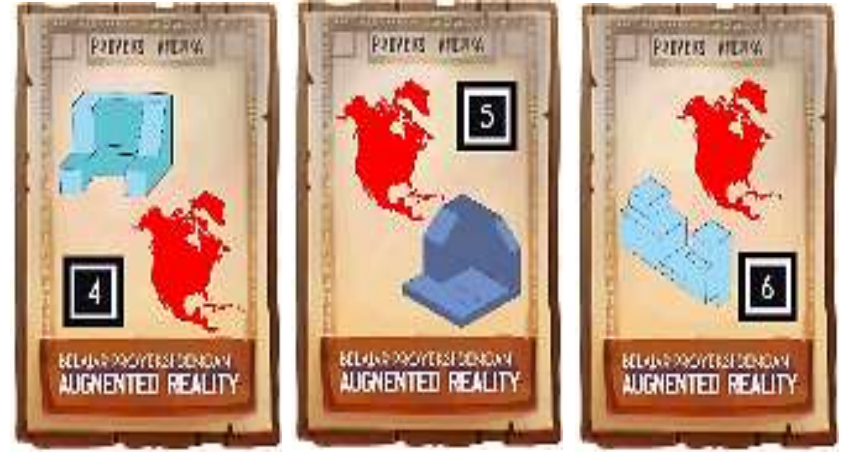

Gambar 4. Desain Marker Proyeksi Amerika

\section{Pengodean}

Tahap pengodean adalah implementasi dari desain yang telah dirancang sesuai dengan desain antarmuka (user interface) dan UML. Desain diterjemahkan dalam bahasa pemrograman $\mathrm{C}+$ dengan Unity $3 D$ sehingga menghasilkan program yang diwujudkan dalam tampilan gambar, teks, objek 3D augmented reality dan musik

\section{Pengujian}

Tahap pengujian yang dilakukan adalah uji materi dan uji media berdasarkan ISO/IEC 25010 menurut teori Ben David yang mengacu pada aspek functional suitability, compatibility, usability dan performance efficiency.

a. Pengujian Aspek Materi

Pengujian materi bertujuan untuk memastikan konten yang ditampilkan dengan aplikasi gambar teknik dengan Augmented Reality ini sudah sesuai dengan sumber materi dan sudah layak untuk digunakan dalam kajian. validasi materi meliputi aspek kualitas isi materi dan aspek kualitas pembelajaran.

Tabel 1. Hasil Analisis Ahli Materi

\begin{tabular}{cccc}
\hline \multirow{4}{*}{ Item } & \multicolumn{2}{c}{ Aspek } & \multirow{2}{*}{ Total } \\
\cline { 2 - 3 } & $\begin{array}{c}\text { Kualitas Isi Dan } \\
\text { Tujuan }\end{array}$ & $\begin{array}{c}\text { Kualitas } \\
\text { Pembelajaran }\end{array}$ & \\
\cline { 2 - 3 }$\%$ & 51 & 38 & 89 \\
\multirow{2}{*}{ kategori } & $91,07 \%$ & $95 \%$ & $92,7 \%$ \\
& Sangat Layak & Sangat Layak & $\begin{array}{c}\text { Sangat } \\
\text { Layak }\end{array}$ \\
\hline
\end{tabular}

Berdasarkan hasil pengujian pada tabel 1 hasil analisis data berdasarkan penilaian ahli materi mendapatkan skor 89 dengan kategori "Sangat Layak". Skor total yang diperoleh dari 2 aspek yaitu aspek kualitasi isi dan tujuan mendapatkan skor 51 dengan kategori "Sangat Layak" dan aspek kualitas pembelajaran mendapatkan rerata skor 38 dengan kategori "Sangat Layak".

b. Pengujian Functional Suitability

Pengujian functional suitability bertujuan mengetahui kemampuan perangkat lunak untuk menyediakan fungsi sesuai kebutuhan pengguna, ketika digunakan dalam kondisi tertentu.

Tabel 2. Hasil Analisis functional suitability

\begin{tabular}{lcc}
\hline \multirow{2}{*}{ Pengguna } & \multicolumn{2}{c}{ Taraf Ketercapaian } \\
\cline { 2 - 3 } & Ya & Tidak \\
\hline Ahli Media & 25 & 0 \\
Total & 25 & 0 \\
\hline
\end{tabular}

Berdasarkan hasil pengujian aspek functional suitability oleh ahli media didapatkan nilai presentase $100 \%$ yang berada pada skala "sangat layak". Hasil konversi dari nilai yang berada pada skala "sangat baik" menunjukkan bahwa fungsi-fungsi dalam media pembelajaran berbasis aplikasi android dengan augmented reality sudah berjalan dengan baik tanpa terdapat fungsi yang gagal (error) dalam menjalankan perintah sistem dalam aplikasi.

c. Pengujian Compatibility

Co-existence menguji sejauh mana produk atau sistem dapat 
menjalankan fungsi yang dibutuhkan secara efisien sementara berbagi sumber daya dengan produk atau sistem lain tanpa merugikan produk atau sistem tersebut.

Nilai persentase kelayakan $100 \%$, sehingga dapat disimpulkan bahwa aplikasi android dengan augmented reality dari sisi co-existence "Sangat Layak".

Hasil uji pada berbagai tipe perangkat dilakukan dengan uji coba langsung pada perangkat android dengan versi, processor, RAM, Kamera dan ukuran layar yang berbeda.

d. Pengujian Usability

\section{Pengujian}

usability

menggunakan System Usability Scale (SUS) yang dikembangkan oleh John Brooke (1986), berjumlah 10 pernyataan dengan jawaban Skala lima. Pengujian dilakukan oleh guru gambar teknik dan 30 siswa kelas $\mathrm{X}$ Kompetensi Keahlian Konstruksi Gedung Sanitasi dan Perawatan di SMK Negeri 1 Seyegan.

Tabel 3. Hasil uji usability

\begin{tabular}{cccc}
\hline $\begin{array}{c}\text { Jumlah } \\
\text { Responden }\end{array}$ & $\begin{array}{c}\text { Rata- } \\
\text { rata }\end{array}$ & $\%$ & Kategori \\
\hline 31 & 79,8 & $\begin{array}{c}79,8 \\
\%\end{array}$ & $\begin{array}{c}\text { Good/ } \\
\text { Baik }\end{array}$ \\
\hline
\end{tabular}

Berdasarkan hasil analisis data pada tabel 8 diperoleh skor rata-rata akhir pengguna adalah 79,8 dengan nilai presentase $79,8 \%$ sehingga dapat disimpulkan bahwa aplikasi android dengan augmented reality memenuhi standar usability menurut pengujian System Usability Scale dengan kategori "Good" atau "Baik" dan tergolong dalam kelas B. e. Pengujian Perfomance Efisiensy

Time behaviour diujikan dengan menghitung rata-rata waktu respon aplikasi untuk launching. Hasil yang diperoleh dibandingkan dengan tabel kepuasan pengguna Hoxmeier dan DiCesare (2000: 347).

Beberapa perangkat dengan spesifikasi yang bebeda diuji waktu launching-nya setelah aplikasi diinstall. Berdasarkan Pengukuran Kepuasan Pengguna menunjukkan bahwa aplikasi berhasil diluncurkan pada beberapa device dengan rata-rata waktu launching 4,02 detik. Sehingga dari aspek performance efficiency berada dalam kriteria "Puas". Dari tabel ini pun terlihat dimana semakin tinggi spesifikasi perangkat android yang digunakan maka semakin cepat juga waktu launching aplikasi.

Penggunaan $C P U$ menunjukkan seberapa besar kinerja $C P U$ dalam menjalankan aplikasi serta penggunaan memory menunjukkan sumber daya yang dibutuhkan ketika menjalankan aplikasi. Hasil pehitungan penggunaan CPU dan memory dalam perhitungan pada tools TestDroid terlihat pada gambar berikut ini.

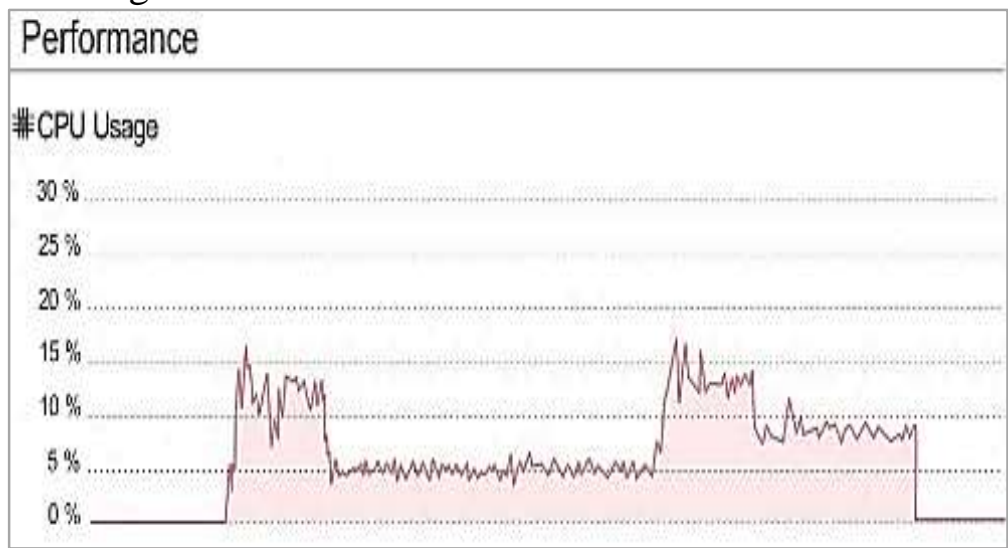

Gambar 5. Penggunaan CPU dalam Aplikasi

Gambar di atas menunjukkan aplikasi ini menggunakan CPU rerata berada pada angka dibawah $10 \%$. Angka tersebut masih berada di bawah 
Pengembangan Media Pelajaran... (Galuh/ hal. 65-77)

batas aman yang ditetapkan oleh Little

Eye (mobile app analysis tools) yaitu $15 \%$.

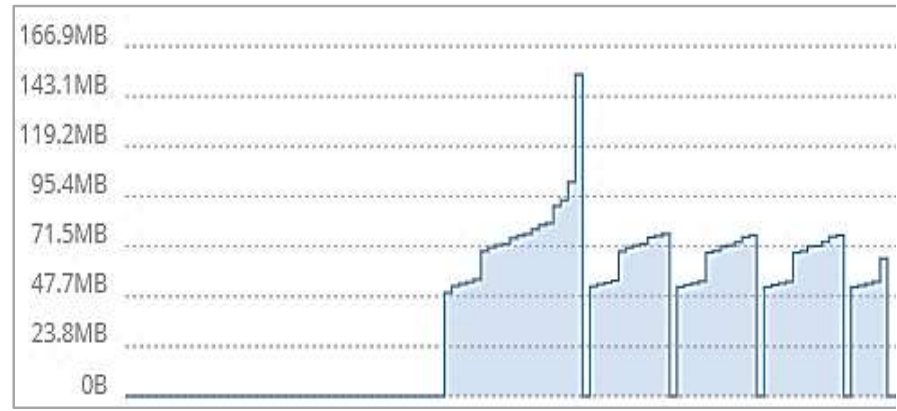

Gambar 6. Penggunaan Memory dalam Aplikasi

\section{SIMPULAN}

Berdasarkan hasil dan pembahasan dalam kajian ini dapat disimpulkan: 1) Tahap analisis didapat permasalahan siswa yakni penggunaan smartphone saat pembelajaran, media kurang variasi dan metode guru mengajar masih konvensional. Software yang digunakan adalah Unity 3D, Source code, Corel Draw X8, dan Adobe Photoshop CS6. Analisis materi pelajaran didapat materi Proyeksi Orthogonal, Proyeksi Eropa dan Proyeksi Amerika; 2) Tahap desain dilakukan pemodelan Unified Modeling Language (UML), dan desain antarmuka (user interface); 3) Tahap pengodean didapat hasil berupa aplikasi android yang diwujudkan dalam tampilan gambar, teks, objek 3D augmented reality

\section{DAFTAR RUJUKAN}

Badan Pusat Statistik. (2018). Berita Resmi

Statistik: Keadaan Ketenagakerjaan Indonesia Februari 2018. Jakarta: Badan Pusat Statistik

Azuma, Ronald T. (1997). A Survey of Augmented Reality. Malibu: Hughes Research Laboratories.
Penggunaan memori atau RAM di angka sekitar $75 \mathrm{MB}$. Penggunaan memory tersebut masih terbilang kecil dibanding RAM minimum perangkat yakni $768 \mathrm{MB}$. Sementara itu, aplikasi juga dapat berjalan tanpa mengalami kekurangan memory yang menyebabkan aplikasi berhenti karena terjadi memory leak. dan musik; 4) Tahap pengujian yang dilakukan adalah uji materi dan uji media berdasarkan ISO/IEC 25010 pada aspek functional suitability, compatibility, usability dan performance efficiency. Kelayakan materi mendapatkan total skor 89 dengan nilai presentase $92,7 \%$ mendapat kategori sangat layak. Aspek functional suitability ahli media mendapatkan nilai 100\% dengan kategori sangat layak. Pada aspek compatibility mendapatkan nilai $100 \%$ dengan kategori sangat layak. Aspek usability memperoleh rata-rata skor 79,8 berada dalam kriteria baik. Pada aspek performance efficiency memperoleh hasil memenuhi dengan standar dan berada pada tingkat performance efficiency yang baik.

David, Assaf Ben. (2011). Mobile Aplication Testing (Best Practices to Ensure Quality). Amdocs.

Sudaryono. (2011). Metode Penelitian Pendidikan. Banten: Dinas Pendidikan Provinsi Banten 
Pengembangan Media Pelajaran... (Galuh/ hal. 65-77)

Sudjana, Nana. (2009). Penilaian Hasil

Proses Belajar Mengajar. Bandung:

PT. Remaja Rosdakarya

Rosa A.S, \& M. Shalahuddin (2016).

Rekayasa Perangkat Lunak

(Terstruktur dan Berorientasi Objek).

Bandung: Informatika.

Ependi et al. (2017). System Usability Scale Antarmuka Palembang Guide Sebagai Media PendukungAsian Games XVIII. Journal of Iinformation System Engineering and Business Intelligence. Vol: 3 